\title{
A High Strength Alumina-Silicon Carbide-Boron Carbide Triplex Ceramic
}

Eric W. Neuman, ${ }^{1}$ Gregory E. Hilmas, ${ }^{2}$ William G. Fahrenholtz

Materials Science and Engineering Dept., Missouri University of Science and Technology, Rolla, MO 65409

\section{Abstract}

A ceramic particulate composite composed of oxide, and carbide ceramics was found to have high strength, hardness, and fracture toughness values. A composition consisting of $\mathrm{Al}_{2} \mathrm{O}_{3}$ with 15 vol\% $\mathrm{SiC}$ and 15 vol\% $\mathrm{B}_{4} \mathrm{C}$ additions was produced by hot-pressing at $1650^{\circ} \mathrm{C}$ for $30 \mathrm{~min}$, with full density reached after $\sim 5$ min at temperature. Both $W B$ and $W B_{2}$ were observed, with the $W$ source presumably an impurity from WC milling media, and $\mathrm{Al}_{18} \mathrm{~B}_{4} \mathrm{O}_{33}$ was also detected following densification. Strength was $\sim 880 \mathrm{MPa}$, which is greater than values reported for comparable composites of $\mathrm{Al}_{2} \mathrm{O}_{3}$ containing 30 vol\% $\mathrm{SiC}$ or $\mathrm{B}_{4} \mathrm{C}$. Vickers hardness was $\sim 21 \mathrm{GPa}$, and fracture toughness was $\sim 4.5 \mathrm{MPa} \cdot \mathrm{m}^{1 / 2}$, comparable to values reported for the binary mixtures. The calculated critical flaw size of the material was similar to the size of the $\mathrm{SiC} / \mathrm{B}_{4} \mathrm{C}$ clusters ofand microcracking at grain boundaries. The latter resulting from thermal expansion mismatch between the $\mathrm{Al}_{2} \mathrm{O}_{3}$ matrix and $\mathrm{SiC} / \mathrm{B}_{4} \mathrm{C}$ reinforcing phases.

\footnotetext{
${ }^{1}$ Present address: Sandia National Laboratories, Albuquerque, NM

${ }^{2}$ Author to whom correspondence should be addressed: 223 McNutt Hall, 1400 N Bishop Ave, Rolla, MO 65409, USA; ghilmas@mst.edu; +1-573-341-6102.
} 


\section{Introduction}

Aluminum oxide $\left(\mathrm{Al}_{2} \mathrm{O}_{3}\right)$ based ceramics have been studied extensively due to their desirable properties such as high hardness, strength, toughness, low electrical conductivity, and good chemical stability.[1] Dispersed, second phase particles of $\mathrm{ZrO}_{2}, \mathrm{SiC}, \mathrm{TiB}_{2}, \mathrm{TiC}, \mathrm{BN}$ and $\mathrm{B}_{4} \mathrm{C}$ have been incorporated into alumina ceramics resulting in improved mechanical properties.[2-9] Strength enhancements have typically been attributed to reduced grain growth during sintering due to grain pinning, while enhanced fracture toughness is due crack bridging and crack deflection as a result of the dispersed second phase.

Incorporation of $\mathrm{SiC}[5,10-13]$ or $\mathrm{B}_{4} \mathrm{C}[3,4,14]$ into $\mathrm{Al}_{2} \mathrm{O}_{3}$ ceramics improved mechanical properties. Shi et al. reported the properties of hot-pressed $\mathrm{Al}_{2} \mathrm{O}_{3}$ with submicron $\mathrm{SiC}$ additions. Strength was reported to increase from $280 \mathrm{MPa}$ for pure $\mathrm{Al}_{2} \mathrm{O}_{3}$ to $615 \mathrm{MPa}$ for 20 vol\% SiC additions, with toughness values as high as $7.6 \mathrm{MPa} \cdot \mathrm{m}^{1 / 2}$ reported for 5 vol\% SiC additions.[5] Additions of SiC nanoparticles $\left(\mathrm{SiC}_{\mathrm{n}}\right)$ to $\mathrm{Al}_{2} \mathrm{O}_{3}$ have led to even greater improvements in strength.[10-13] Chae et al. reported a strength of $810 \mathrm{MPa}$ for $\mathrm{Al}_{2} \mathrm{O}_{3}-20$ vol\% SiC . [12] The high strength was attributed to increased propensity for transgranular fracture when SiC was present due to the presence of thermal residual stresses arising from the mismatch in coefficient of thermal expansion (CTE) between $\mathrm{Al}_{2} \mathrm{O}_{3}\left(8 \times 10^{-6} / \mathrm{K}\right)$ and $\operatorname{SiC}\left(4.2 \times 10^{-6} / \mathrm{K}\right)$, which led to the formation of residual stresses during cooling from processing temperatures. Similar improvements have been reported for $\mathrm{Al}_{2} \mathrm{O}_{3}-\mathrm{B}_{4} \mathrm{C}$ ceramics. Liu and Ownby reported an increase in strength for hot-pressed $\mathrm{Al}_{2} \mathrm{O}_{3}-\mathrm{B}_{4} \mathrm{C}$ with up to 30 vol\% $\mathrm{B}_{4} \mathrm{C}$ from $\sim 20 \mathrm{MPa}$ for pure $\mathrm{Al}_{2} \mathrm{O}_{3}$ to $\sim 580 \mathrm{MPa}$ for $\mathrm{Al}_{2} \mathrm{O}_{3}-\mathrm{B}_{4} \mathrm{C}$, with fracture toughness increasing from $\sim 4.0 \mathrm{MPa} \cdot \mathrm{m}^{1 / 2}$ to between 4.7 and 5.3 MPa.m $\mathrm{m}^{1 / 2}$ for the two phase ceramics.[3] Jung and Kim investigated the $\mathrm{Al}_{2} \mathrm{O}_{3}-\mathrm{B}_{4} \mathrm{C}$ system, reporting improvement in strength (325 to $550 \mathrm{MPa}$ ), toughness $\left(2.4\right.$ to $\left.4.0 \mathrm{MPa} \cdot \mathrm{m}^{1 / 2}\right)$ and hardness $(15.2$ to $20.6 \mathrm{GPa}$ ) as a result of the finer grain size produced by grain pinning of the $\mathrm{Al}_{2} \mathrm{O}_{3}$ by the $\mathrm{B}_{4} \mathrm{C}$ during sintering, and crack deflection around $\mathrm{B}_{4} \mathrm{C}$ grains.[4] 
Investigation of the processing and properties of ternary $\mathrm{Al}_{2} \mathrm{O}_{3}-\mathrm{SiC}-\mathrm{B}_{4} \mathrm{C}$ ceramics is scarce.

Swarnakar et al. investigated a $\mathrm{Al}_{2} \mathrm{O}_{3}-60 \mathrm{vol} \% \mathrm{~B}_{4} \mathrm{C}$ composite with up to $5 \mathrm{wt} \% \mathrm{SiC}$ carbide additions densified by pulsed electric current sintering (PECS).[15] Flexure strength, hardness, and toughness for the $\mathrm{Al}_{2} \mathrm{O}_{3}-60$ vol\% $\mathrm{B}_{4} \mathrm{C}$ ceramic were reported as $595 \mathrm{MPa}, 24.3 \mathrm{GPa}$, and 7.2 MPa.m $\mathrm{m}^{1 / 2}$, respectively, and remained unchanged with up to $5 \mathrm{wt} \%$ addition of $\mathrm{SiC}$. Grains of an aluminum borate phase $\left(\mathrm{Al}_{18} \mathrm{~B}_{4} \mathrm{O}_{33}\right)$ were found in the microstructure following PECS, which was attributed to the thermodynamically favorable reduction of $\mathrm{Al}_{2} \mathrm{O}_{3}$ by $\mathrm{B}_{4} \mathrm{C}$. Previous studies into alumina based ternary ceramics have investigated additions of $\mathrm{SiC} / \mathrm{TiC},[16,17] \mathrm{WC} / \mathrm{TiC},[17,18] \mathrm{ZrO}_{2} / \mathrm{TiC},[17]$ and $\mathrm{ZrB}_{2} / \mathrm{ZrO}_{2}[19]$ while several other studies have investigated the properties of $\mathrm{ZrO}_{2}-\mathrm{Al}_{2} \mathrm{O}_{3}-\mathrm{TiC},[20] \mathrm{TiB}_{2}-\mathrm{TiC}-\mathrm{SiC},[21,22]$ and $\mathrm{ZrB}_{2}-\mathrm{SiC}-$ $\mathrm{B}_{4} \mathrm{C}[23]$ ceramics. In each of these systems, properties of the ternary ceramics were found to be improved compared to their constituent phases. The ternary ceramics also provide the promise of improved tailoring of properties such as strength, toughness, hardness, and electrical conductivity. For example, $\mathrm{Al}_{2} \mathrm{O}_{3}-\mathrm{WC}-\mathrm{TiC}$ ceramics were promising ceramic tooling materials that could be shaped by electrical discharge machining.[17, 18, 24]

The purpose of the present study was to examine the densification behavior, microstructure, and mechanical properties of $\mathrm{Al}_{2} \mathrm{O}_{3}-\mathrm{SiC}-\mathrm{B}_{4} \mathrm{C}$ ceramics.

\section{Experimental}

Commercially available powders were used to prepare the ceramics in this study, which contained 70 vol\% $\mathrm{Al}_{2} \mathrm{O}_{3}, 15$ vol\% $\mathrm{SiC}$, and 15 vol\% $\mathrm{B}_{4} \mathrm{C}$ (designated $\mathrm{ASB}$ ). The $\mathrm{Al}_{2} \mathrm{O}_{3}$ powder (Grade $\mathrm{A} 16-$ SG, Almatis Inc., Leetsdale, PA) had a reported purity of $99.8 \%$ and a starting particle size of $0.5 \mu \mathrm{m}$. The SiC powder (Grade UF-25, H. C. Starck, Newton, MA) was predominantly $\alpha$-SiC with a reported purity of $>97.4 \%$ and a particle size of $0.45 \mu \mathrm{m}$. The $\mathrm{B}_{4} \mathrm{C}$ powder (Grade HS, H. C. Starck) had a reported purity of $>96.8 \%, \mathrm{a} \mathrm{B} / \mathrm{C}$ ratio of 3.8 , and starting particle sizes that ranged from 0.6 to $1.2 \mu \mathrm{m}$. The powders were ball milled in methyl-ethyl ketone with dispersant (DISPERBYK-110, BYK- USA Inc., Wallingford, CT) at 60 
rpm for $24 \mathrm{~h}$ in a polyethylene jar, using cobalt-bonded tungsten carbide media. Solvent was removed from the milled slurry using rotary evaporation (Rotavapor R-124, Buchi, Flawil, Germany) at a temperature of $80^{\circ} \mathrm{C}$, a vacuum of $\sim 27 \mathrm{kPa}$, and a rotation speed of $90 \mathrm{rpm}$. Dried powders were lightly ground and passed through a 50 mesh screen before densification.

Blended powders were hot pressed (HP-3060, Thermal Technology, Santa Rosa, CA) in graphite die lined with graphite foil (GRAFOIL@ Grade GTA, GrafTech International Holdings, Inc., Independence, $\mathrm{OH}$ ) and coated with BN (SP-108, Materion Advanced Materials Group, Milwaukee, WA). Above $\sim 600^{\circ} \mathrm{C}$, the temperature of the graphite die was monitored using an infrared pyrometer (OS 3708, Omega Engineering, Stamford, CT). Powder compacts were heated under flowing argon to $1200^{\circ} \mathrm{C}$ with an average heating rate of $\sim 60^{\circ} \mathrm{C} / \mathrm{min}$, when a uniaxial load was applied at $\sim 6 \mathrm{MPa} / \mathrm{min}$ to $32 \mathrm{MPa}$ while continuing to heat to $1650^{\circ}$. Compacts were held at $1650^{\circ} \mathrm{C}$ for $30 \mathrm{~min}$ for densification, the furnace was then cooled at $\sim 10^{\circ} \mathrm{C} / \mathrm{min}$ to room temperature. The load was removed when the die temperature dropped below $1250^{\circ} \mathrm{C}$. Surfaces of hot-pressed billets were surface ground to a 120 grit finish to remove residual $\mathrm{BN}$ and graphite foil.

Bulk densities of the hot-pressed billets were determined using Archimedes' method with distilled water as the immersing medium. Microstructures were examined using scanning electron microscopy (SEM; Helios Nano Lab 600, Hillsboro, OR). Specimens were prepared for microscopy by cutting cross sections perpendicular to the hot-pressing direction and polishing to a $0.25 \mu \mathrm{m}$ finish using progressively finer diamond abrasives.

Hardness was measured by Vickers indentation (Duramin V, Struers, Westlake, OH) using a load of $9.8 \mathrm{~N}$ and a dwell time of $15 \mathrm{~s}$ according to ASTM C1327. Ten indents were measured to determine the reported average values. Elastic modulus was calculated from load-deflection data collected during strength testing using a deflectometer. Flexure strengths were measured in four-point bending using a semi-articulated test fixture using type A bars $(25 \mathrm{~mm} \times 2.0 \mathrm{~mm} \times 1.5 \mathrm{~mm})$ according to ASTM C1161. 
Bars were machined from the hot-pressed billets by diamond grinding on a fully automated surface grinder (FSG-3A818, Chevalier, Santa Fe Springs, CA), and fine ground to final dimensions using a 600grit diamond grinding wheel. The flexure surface was polished to a $1 \mu \mathrm{m}$ surface finish using diamond abrasives. Tests were performed using a screw-driven instrumented load frame (Model 5881, Instron, Norwood, MA). Fracture toughness was measured according to the direct crack method of Anstis et al.[25] A Vickers indent was made using a load of $10 \mathrm{~kg}$ and a dwell time of $15 \mathrm{~s}$. Ten indents were measured to determine the average crack length.

\section{Results and Discussion}

The measured bulk density was $3.636 \mathrm{~g} / \mathrm{cm}^{3}$ for the hot pressed composite, which was close to the theoretical density of $3.625 \mathrm{~g} / \mathrm{cm}^{3}$ predicted for the nominal composition. The bulk density is higher than the predicted theoretical density for a combination of reasons: (1) incorporation of Co-bonded WC $\left(\rho=14.6 \mathrm{~g} / \mathrm{cm}^{3}\right)$ impurities during ball milling of the powder; $(2)$ loss of $\mathrm{SiC}\left(3.21 \mathrm{~g} / \mathrm{cm}^{3}\right)$ and $\mathrm{B}_{4} \mathrm{C}(2.52$

$\mathrm{g} / \mathrm{cm}^{3}$ ) due to reaction with oxygen; and (3) formation of a new phase from reaction of $\mathrm{SiC}$ and $\mathrm{B}_{4} \mathrm{C}$ with $\mathrm{Al}_{2} \mathrm{O}_{3}$. The additional phases present following hot pressing were identified by XRD (Figure 1). In addition to $\mathrm{Al}_{2} \mathrm{O}_{3}, \mathrm{SiC}$, and $\mathrm{B}_{4} \mathrm{C}, \mathrm{WB}, \mathrm{WB}_{2}$, and $\mathrm{Al}_{18} \mathrm{~B}_{4} \mathrm{O}_{33}$ were detected by $\mathrm{XRD}$. WB and $\mathrm{WB}_{2}$ are likely formed from a multistep reaction of the WC, introduced by erosion of milling media, with $\mathrm{Al}_{2} \mathrm{O}_{3}$ and $\mathrm{B}_{4} \mathrm{C}$. $\mathrm{Al}_{18} \mathrm{~B}_{4} \mathrm{O}_{33}$ has previously been shown to form from the reaction of $\mathrm{Al}_{2} \mathrm{O}_{3}$ with $\mathrm{B}_{4} \mathrm{C}$.[15] Although the relative density could not be determined because the true density of the composite was not known, bulk density measurements indicated that the composite likely had high relative density.

The microstructure of the ceramics was examined by SEM (Figure 2) and by STEM (Figure 3). $\mathrm{Al}_{2} \mathrm{O}_{3}$ was the lighter gray phase and formed a continuous matrix with grain sizes of less than about 3 $\mu \mathrm{m}$. SiC appeared as a slightly darker gray phase and was present as isolated particles. Some of the particles were equiaxed with diameters of up to $\sim 1 \mu \mathrm{m}$, while others were elongated with thicknesses 
on the order $0.5 \mu \mathrm{m}$ with lengths up to $\sim 3 \mu \mathrm{m} . \mathrm{B}_{4} \mathrm{C}$ appeared dark gray and was present as isolated, equiaxed grains with diameters of less than about $3 \mu \mathrm{m}$; however, some $\mathrm{B}_{4} \mathrm{C}$ clusters composed of several particles were observed. The clusters were large as $\sim \mu \mathrm{m}$. A small volume fraction of $B N$ and $\mathrm{WB}_{\mathrm{x}}$ were observed, mainly at the grain boundaries. $\mathrm{BN}$ formed elongated lamellar inclusions of less than $\sim 0.2 \mu \mathrm{m}$ in width with lengths up to $\sim 1.5 \mu \mathrm{m}$. The $\mathrm{WB}_{\mathrm{x}}$ phases were present as equiaxed particles of less than $\sim 0.2 \mu \mathrm{m}$. A small volume fraction (less than 1 vol\%) of porosity was observed as small features primarily located at triple grain junctions, and as internal porosity in larger $\mathrm{B}_{4} \mathrm{C}$ grains/clusters. In addition, a fine $(<0.1 \mu \mathrm{m})$, intragranular, low- $Z$ phase was present in some $\mathrm{Al}_{2} \mathrm{O}_{3}$ grains. This feature is likely $\mathrm{SiC}$ similar to what has previously been reported by Sternitzke et al.[13] The $\mathrm{Al}_{18} \mathrm{~B}_{4} \mathrm{O}_{33}$ phase identified by XRD was not distinguishable by SEM, presumably due to its similar Z-contrast to $\mathrm{Al}_{2} \mathrm{O}_{3}$; however, indications of a liquid phase were present at the grain boundaries in the STEM images. These regions could be $\mathrm{Al}_{18} \mathrm{~B}_{4} \mathrm{O}_{33}$, which is expected to be liquid above $\sim 1450^{\circ} \mathrm{C}$.[26]

The densification behavior of the composite is shown in Figure 4. The onset of densification occurred almost simultaneously with the application of the load of $\sim 5 \mathrm{MPa}$ at $\sim 1225^{\circ} \mathrm{C}$ during hot pressing. The ceramics reached full density after $\sim 4 \mathrm{~min}$ at the maximum hot-pressing temperature of $1650^{\circ} \mathrm{C}$. The initial observed densification was likely facilitated by particle rearrangement and compaction aided by formation of a liquid borate and aluminum borate phase.[26] Intermediate and final stage sintering likely occurred through a combination of liquid phase and solid state sintering, as the liquid phase was only observed at a limited amount of grain boundary interfaces. The formation of the aluminum borate phase has been predicted to occur at temperatures as low as $1000^{\circ} \mathrm{C}$ by thermodynamic calculations assuming amorphous $\mathrm{B}_{2} \mathrm{O}_{3}$ (a known surface impurity on fine $\mathrm{B}_{4} \mathrm{C}$ powders) and $\mathrm{Al}_{2} \mathrm{O}_{3}$ by Swarnakar et al.[15] Additionally, the direct reaction of $\mathrm{B}_{4} \mathrm{C}$ with $\mathrm{Al}_{2} \mathrm{O}_{3}$ was predicted to form $\mathrm{Al}_{18} \mathrm{~B}_{4} \mathrm{O}_{33}$ at $1650^{\circ} \mathrm{C} .[15]$ 
Young's modulus four-point flexure strength, Vickers hardness, and fracture toughness were measured (Table I). Young's modulus was $408 \mathrm{GPa}$, which is similar to reported values for $\mathrm{Al}_{2} \mathrm{O}_{3}$ ceramics ( $\sim 10 \mathrm{GPa}),[27]$ even though the value was expected to increase due to the additions of SiC ( 415 $\mathrm{GPa})[28]$ and $\mathrm{B}_{4} \mathrm{C}$ ( 455 GPa),[29] and from the incorporation of WC ( $\left.640 \mathrm{GPa}\right)[30]$ during milling. Presence of the aluminum borate may decrease the modulus of the final ceramic due to its lower Young's modulus (400 GPa).[31] In addition, microcracking could also reduce Young's modulus. Fracture toughness was $\sim 4.5 \mathrm{MPa} \cdot \mathrm{m}^{1 / 2}$, similar to previously reported values for $\mathrm{Al}_{2} \mathrm{O}_{3}-\mathrm{B}_{4} \mathrm{C}$ ceramics $(\sim 3.5-5.5$ $\left.\mathrm{MPa} \cdot \mathrm{m}^{1 / 2}\right)[3,4,14,15]$ and $\mathrm{Al}_{2} \mathrm{O}_{3}-\mathrm{SiC}$ ceramics $\left(\sim 2.5-7.5 \mathrm{MPa} \cdot \mathrm{m}^{1 / 2}\right) \cdot[5,11-13]$ Figure 5 shows a radial/median crack originating from the Vickers indent used to measure toughness. The crack exhibited some deflection when encountering $\mathrm{SiC}$ and $\mathrm{B}_{4} \mathrm{C}$ particles, though no bridging was observed. The fracture mode was found to be predominantly transgranular through the $\mathrm{SiC}$ and $\mathrm{B}_{4} \mathrm{C}$ grains, while exhibiting mixed mode transgranular and intergranular fracture through the $\mathrm{Al}_{2} \mathrm{O}_{3}$ phase. Vickers microhardness was $\sim 21 \mathrm{GPa}$, in agreement with previous studies for $\mathrm{Al}_{2} \mathrm{O}_{3}-\mathrm{SiC}$ ( $\left.\sim 15-23 \mathrm{GPa}\right)[5,11-13]$ and $\mathrm{Al}_{2} \mathrm{O}_{3}-\mathrm{B}_{4} \mathrm{C}$ ( $\left.15-21 \mathrm{GPa}\right)$.[4] Hardness of the present material was less than reported for the $\mathrm{B}_{4} \mathrm{C}$ $\mathrm{Al}_{2} \mathrm{O}_{3}$-SiC ceramic ( $26 \mathrm{GPa}$ ) due to $\mathrm{B}_{4} \mathrm{C}$ being the continuous matrix phase in Swarnakar's material, compared to the continuous $\mathrm{Al}_{2} \mathrm{O}_{3}$ matrix in the present study.[15]

Flexure strength was $\sim 880 \mathrm{MPa}$, which is greater than comparable $\mathrm{Al}_{2} \mathrm{O}_{3}-\mathrm{SiC}(\sim 300-750$ $\mathrm{MPa})[5,11-13]$ and $\mathrm{Al}_{2} \mathrm{O}_{3}-\mathrm{B}_{4} \mathrm{C}(\sim 200-600 \mathrm{MPa})[3,4,14]$ ceramics, and $\sim 50 \%$ greater than previously reported $\mathrm{B}_{4} \mathrm{C}-\mathrm{Al}_{2} \mathrm{O}_{3}-\mathrm{SiC}$ ( $\left.\sim 900-600 \mathrm{MPa}\right)$.[15] This improvement is likely due favorable residual stress states in the ceramic that formed due to the CTE mismatch between $\mathrm{Al}_{2} \mathrm{O}_{3}\left(7.2-8.6 \times 10^{-6} / \mathrm{K}\right)[32]$ and $\operatorname{SiC}\left(4.3-5.6 \times 10^{-6} / \mathrm{K}\right)$,[32] $\mathrm{B}_{4} \mathrm{C}\left(5.7 \times 10^{-6} / \mathrm{K}\right),[33]$ and $\mathrm{Al}_{18} \mathrm{~B}_{4} \mathrm{O}_{33}\left(3-5 \times 10^{-6} / \mathrm{K}\right)$. [34] The difference in CTE between the matrix and reinforcing phases places the $\mathrm{Al}_{2} \mathrm{O}_{3}$ matrix under a tensile stress state, while the reinforcing phases experience a compressive stress state. This behavior was investigated by Ferroni and Pezzotti for the $\mathrm{Al}_{2} \mathrm{O}_{3}-\mathrm{SiC}$ system.[10] Ferroni and Pezzotti demonstrated that additions of SiC 
nanoparticles to $\mathrm{Al}_{2} \mathrm{O}_{3}$ improved the fracture strength of the composite through an increase in the amount of transgranular fracture and a favorable bulk residual stress state that strengthened the $\mathrm{Al}_{2} \mathrm{O}_{3}$ grain boundaries, with the maximum effect occurring for SiC additions up to 10 vol\%.

Residual stresses in the present material were large enough to cause spontaneous grain boundary microcracking between $\mathrm{Al}_{2} \mathrm{O}_{3}$ and $\mathrm{SiC} / \mathrm{B}_{4} \mathrm{C}$ grains and clusters (Figure 6). The presence of microcracking is expected to decreased hardness and modulus compared to materials without microcracking. Griffith type analysis using a Y-parameter of 1.99 (long, elliptical surface crack where c > 2a) results in a calculated critical flaw size of $\sim 7 \mu \mathrm{m}$. This is similar to the size ( $\sim 6-8 \mu \mathrm{m})$ and shape (aspect ratio $>2$ ) of the largest $\mathrm{SiC} / \mathrm{B}_{4} \mathrm{C}$ clusters present in the microstructure, in addition to the microcracking that accompanies these features. Thus, it is proposed that the strength limiting feature in the present material is the $\mathrm{SiC} / \mathrm{B}_{4} \mathrm{C}$ clusters and accompanying spontaneous microcracking along the $\mathrm{SiC} / \mathrm{B}_{4} \mathrm{C}-\mathrm{Al}_{2} \mathrm{O}_{3}$ boundaries. Strength, hardness, and modulus improvements of the $\mathrm{Al}_{2} \mathrm{O}_{3}-\mathrm{SiC}-\mathrm{B}_{4} \mathrm{C}$ system are likely to be realized through reducing the degree of percolation of the $\mathrm{SiC} / \mathrm{B}_{4} \mathrm{C}$ phase in the $\mathrm{Al}_{2} \mathrm{O}_{3}$ matrix to a level below the critical microcracking threshold.

\section{Summary}

The microstructure, processing, and properties was reported for a three phase ceramic consisting of 70 vol\% $\mathrm{Al}_{2} \mathrm{O}_{3}, 15$ vol\% $\mathrm{SiC}$, and 15 vol\% $\mathrm{B}_{4} \mathrm{C}$ that was produced from commercially available powders. The composition reached near full density by hot-pressing at $1650^{\circ} \mathrm{C}$ for $30 \mathrm{~min}$. In addition to $\mathrm{Al}_{2} \mathrm{O}_{3}, \mathrm{SiC}$, and $\mathrm{B}_{4} \mathrm{C}$, additional phases of $\mathrm{WB}, \mathrm{WB}_{2}$, and $\mathrm{Al}_{18} \mathrm{~B}_{4} \mathrm{O}_{33}$ were present following densification. $\mathrm{Al}_{18} \mathrm{~B}_{4} \mathrm{O}_{33}$ may form from the reaction between $\mathrm{Al}_{2} \mathrm{O}_{3}$ and the $\mathrm{B}_{2} \mathrm{O}_{3}$ present on the surface of the $\mathrm{B}_{4} \mathrm{C}$ powder beginning at $1000^{\circ} \mathrm{C}$, or direct reaction between $\mathrm{Al}_{2} \mathrm{O}_{3}$ and $\mathrm{B}_{4} \mathrm{C}$ at the processing temperature. The formation of aluminum borate during hot-pressing results in liquid phase sintering for process temperatures above $\sim 1450^{\circ} \mathrm{C}$. Measured flexure strength was $\sim 880 \mathrm{MPa}$, Vickers hardness was $\sim 21$ $\mathrm{GPa}$, and fracture toughness was $\sim 4.5 \mathrm{MPa} \cdot \mathrm{m}^{1 / 2}$. The strength limiting flaw in the material suggested to be 
$\mathrm{SiC} / \mathrm{B}_{4} \mathrm{C}$ clusters which were directly associated with grain boundary microcracking, resulting from CTE mismatch between the $\mathrm{Al}_{2} \mathrm{O}_{3}$ matrix and $\mathrm{SiC} / \mathrm{B}_{4} \mathrm{C}$ reinforcing phases. Based on these results, the $\mathrm{Al}_{2} \mathrm{O}_{3^{-}}$ SiC- $\mathrm{B}_{4} \mathrm{C}$ system offers a promising approach to improvement in the strength of alumina based ceramics using conventional processing methods and commercially available powders.

\section{Acknowledgements}

The authors would like to thank the Missouri S\&T Advanced Materials Characterization

Laboratory, and Dr. Eric Bohannan for performing the XRD analysis. This work was financially supported by the National Science Foundation [grants DMR 0346800 and 0906584]. 


\section{References}

[1] R.G. Munro, Evaluated material properties for a sintered $\alpha$-alumina, J. Am. Ceram. Soc., 80 (1997) 1919-1928.

[2] J. Liu, P.D. Ownby, Enhanced mechanical properties of alumina by dispersed titanium diboride particulate inclusions, J. Am. Ceram. Soc., 74 (1991) 241-243.

[3] J. Liu, P.D. Ownby, Boron carbide reinforced alumina composites, J. Am. Ceram. Soc., 74 (1991) 674-677.

[4] C.H. Jung, C.H. Kim, Sintering and characterization of $\mathrm{Al}_{2} \mathrm{O}_{3}-\mathrm{B}_{4} \mathrm{C}$ composites, J. Mater. Sci., 26 (1991) 5037-5040.

[5] X. Shi, F. Xu, Z. Zhang, Y. Dong, Y. Tan, L. Wang, J. Yang, Mechanical properties of hot-pressed $\mathrm{Al}_{2} \mathrm{O}_{3} / \mathrm{SiC}$ composites. Mat. Sci. Eng. A, 527 (2010) 4646-4649.

[6] R.P. Wahi, B. Ilschner, Fracture behaviour of composites based on $\mathrm{Al}_{2} \mathrm{O}_{3}$-TiC, J. Mater. Sci., 15 (1980) 875-885.

[7] R.A. Cutler, A.C. Hurford, A.V. Virkar, Pressureless-sintered $\mathrm{Al}_{2} \mathrm{O}_{3}$-TiC composites, Mater. Sci. Eng., 105-106 (1988) 183-192.

[8] N. Claussen, Fracture Toughness of $\mathrm{Al}_{2} \mathrm{O}_{3}$ with an Unstabilized $\mathrm{ZrO}_{2}$ Dispersed Phase, J. Am. Ceram. Soc., 59 (1976) 49-51.

[9] Y. Li, G. Qiao, Z. Jin, Machinable $\mathrm{Al}_{2} \mathrm{O}_{3} / \mathrm{BN}$ composite ceramics with strong mechanical properties, Mater. Res. Bull., 37 (2002) 1401-1409.

[10] L.P. Ferroni, G. Pezzotti, Evidence for bulk Residual stress strengthening in $\mathrm{Al}_{2} \mathrm{O}_{3} / \mathrm{SiC}$ nanocomposites, J. Am. Ceram. Soc., 85 (2002) 2033-2038.

[11] X. Sun, J.-G. Li, S. Guo, Z. Xiu, K. Duan, X.Z. Hu, intragranular particle residual stress strengthening of $\mathrm{Al}_{2} \mathrm{O}_{3}-\mathrm{SiC}$ nanocomposites, J. Am. Ceram. Soc., 88 (2005) 1536-1543.

[12] J.H. Chae, K.H. Kim, Y.H. Choa, J.I. Matsushita, J.W. Yoon, K.B. Shim, Microstructural evolution of $\mathrm{Al}_{2} \mathrm{O}_{3}-\mathrm{SiC}$ nanocomposites during spark plasma sintering, J. Alloys Compd., 413 (2006) 259-264.

[13] M. Sternitzke, B. Derby, R.J. Brook, Alumina/silicon carbide nanocomposites by hybrid polymer/powder processing: microstructures and mechanical properties, J. Am. Ceram. Soc., 81 (1998) 41-48.

[14] X. Lin, P.D. Ownby, Pressureless sintering of $\mathrm{B}_{4} \mathrm{C}$ whisker reinforced $\mathrm{Al}_{2} \mathrm{O}_{3}$ matrix composites, J. Mater. Sci., 35 (2000) 411-418.

[15] A.K. Swarnakar, S. Huang, O. Van der Biest, J. Vleugels, Ultrafine $\mathrm{Al}_{2} \mathrm{O}_{3}-\mathrm{B}_{4} \mathrm{C}$ composites consolidated by pulsed electric current sintering, J. Alloys Compd., 499 (2010) 200-205. 
[16] B. Smirnov, V. Nikolaev, T. Orlova, V. Shpeizman, A. de Arellano-López, K. Goretta, D. Singh, J. Routbort, Mechanical properties and microstructure of an $\mathrm{Al}_{2} \mathrm{O}_{3}-\mathrm{SiC}-\mathrm{TiC}$ composite, Mat. Sci. Eng. A, 242 (1998) 292-295.

[17] R. Landfried, F. Kern, W. Burger, W. Leonhardt, R. Gadow, development of electrical discharge machinable ZTA ceramics with 24 vol\% of TiC, TiN, TiCN, $\mathrm{TiB}_{2}$ and $\mathrm{WC}$ as electrically conductive phase, Int. J. Appl. Ceram. Technol., 10 (2013) 509-518.

[18] J. Zhao, X. Yuan, Y. Zhou, Processing and characterization of an $\mathrm{Al}_{2} \mathrm{O}_{3} / \mathrm{WC} / \mathrm{TiC}$ micro- nanocomposite ceramic tool material, Mat. Sci. Eng. A, 527 (2010) 1844-1849.

[19] B. Li, J. Deng, Z. Wu, Effect of cutting atmosphere on dry machining performance with $\mathrm{Al}_{2} \mathrm{O}_{3} / \mathrm{ZrB}_{2} / \mathrm{ZrO}_{2}$ ceramic tool, Int. J. Adv. Manuf. Tech., 49 (2010) 459-467.

[20] M. Fukuhara, Properties of $(\gamma) \mathrm{ZrO}_{2}-\mathrm{Al}_{2} \mathrm{O}_{3}$ and $(\gamma) \mathrm{ZrO}_{2}-\mathrm{Al}_{2} \mathrm{O}_{3}-(\mathrm{Ti}$ or Si)C Composites, J. Am. Ceram. Soc., 72 (1989) 236-242.

[21] F. De Mestral, F. Thevenot, Ceramic composites: TiB 2 -TiC-SiC Part I properties and microstructures in the ternary system, J. Mater. Sci., 26 (1991) 5547-5560.

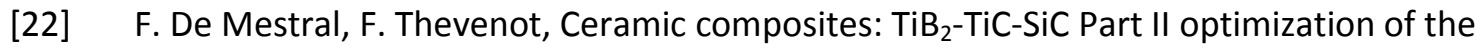
composite 20\% $\mathrm{TiB}_{2}-55 \%$ (mol\%) TiC-25\% SiC, J. Mater. Sci., 26 (1991) 5561-5565.

[23] W.G. Fahrenholtz, E.W. Neuman, H.J. Brown-Shaklee, G.E. Hilmas, Superhard boride-carbide particulate composites, J. Am. Ceram. Soc., 93 (2010) 3580-3583.

[24] J. Zhao, X. Yuan, Y. Zhou, Cutting performance and failure mechanisms of an $\mathrm{Al}_{2} \mathrm{O}_{3} / \mathrm{WC} / \mathrm{TiC}$ micro-nano-composite ceramic tool, Int. J. Refract. Met. Hard Mater., 28 (2010) 330-337.

[25] G.R. Anstis, P. Chantikul, B.R. Lawn, D.B. Marshall, A critical evaluation of indentation techniques for measuring fracture toughness: I, direct crack measurements, J. Am. Ceram. Soc., 64 (1981) 533-538.

[26] P.J.M. Gielisse, W.R. Foster, The system $\mathrm{Al}_{2} \mathrm{O}_{3}-\mathrm{B}_{2} \mathrm{O}_{3}$, Nature, 195 (1962) 69-70.

[27] F.P. Knudsen, Effect of porosity on Young's modulus of alumina, J. Am. Ceram. Soc., 45 (1962) 94-95.

[28] R. Munro, Material properties of a sintered $\alpha$-SiC, J. Phys. Chem. Ref. Data, 26 (1997) 1195-1203.

[29] S. Dodd, G. Saunders, B. James, Temperature and pressure dependences of the elastic properties of ceramic boron carbide $\left(B_{4} C\right)$, J. Mater. Sci., 37 (2002) 2731-2736.

[30] P.T.B. Shaffer, Engineering properties of carbides, in: S.J.S. Schneider Jr (Ed.), Ceramics and Glasses: Engineered Materials Handbook, ASM International, Materials Park, OH, 1991, pp. 787803. 
[31] S.C. Tjong, W. Jiang, Mechanical and thermal behavior of polycarbonate composites reinforced with aluminum borate whiskers, J. Appl. Polym. Sci., 73 (1999) 2247-2253.

[32] W.J. Lackey, D.P. Stinton, G.A. Cermy, A.C. Schaffhauser, L.L. Fehrenbacher, Ceramic coatings for advanced heat engines - a review and projection, Adv. Ceram. Mater., (1987) 24-330.

[33] F. Thevenot, Boron carbide-a comprehensive review, J. Eur. Ceram. Soc., 6 (1990) 205-225.

[34] S.P. Ray, Preparation and characterization of aluminum borate, J. Am. Ceram. Soc., 75 (1992) 2605-2609. 
Table I. Physical and mechanical properties of $\mathrm{Al}_{2} \mathrm{O}_{3}-\mathrm{SiC}-\mathrm{B}_{4} \mathrm{C}$ ceramic hot-pressed at $1650^{\circ} \mathrm{C}$

\begin{tabular}{lc}
\hline Property & Value \\
\hline Bulk density & $3.636 \mathrm{~g} / \mathrm{cm}^{3}$ \\
Young's modulus & $408 \pm 8 \mathrm{GPa}$ \\
Flexure strength & $876 \pm 103 \mathrm{MPa}$ \\
Fracture toughness & $4.5 \pm 0.2 \mathrm{MPa} \cdot \mathrm{m}^{1 / 2}$ \\
Vickers hardness & $21.2 \pm 0.8 \mathrm{GPa}$ \\
\hline
\end{tabular}




\section{List of Figures}

Figure 1. XRD pattern of the hot-pressed $\mathrm{Al}_{2} \mathrm{O}_{3}-\mathrm{SiC}-\mathrm{B}_{4} \mathrm{C}$ composite.

Figure 2. SEM micrograph of the $\mathrm{Al}_{2} \mathrm{O}_{3}-\mathrm{SiC}-\mathrm{B}_{4} \mathrm{C}$ ceramic. $\mathrm{Al}_{2} \mathrm{O}_{3}$ and $\mathrm{SiC}$ are the medium grey phase, with similar Z-contrast, $\mathrm{B}_{4} \mathrm{C}$ is the darker grey phase, $\mathrm{WB}_{\mathbf{x}}$ is isolated white particles. Notice the intragranular porosity present in the $\mathrm{B}_{4} \mathrm{C}$ phase.

Figure 3. DF STEM image of $\mathrm{Al}_{2} \mathrm{O}_{3}-\mathrm{SiC}-\mathrm{B}_{4} \mathrm{C}$ highlighting the presence of $\mathrm{W}$-containing high- $\mathrm{Z}$ phase along grain boundaries (a) and HAADF STEM image highlighting low-Z phase intragranular to $\mathrm{Al}_{2} \mathrm{O}_{3}(b)$.

Figure 4. Relative density, furnace temperature, and pressure as a function of hot-pressing time.

Figure 5. (a) Optical micrograph of the DCM Vickers indent, and (b) SEM micrograph of a radial median crack, in the $\mathrm{Al}_{2} \mathrm{O}_{3}-\mathrm{SiC}-\mathrm{B}_{4} \mathrm{C}$ ceramic.

Figure 6. SEM micrograph of microcracking at the grain boundary interface of $\mathrm{Al}_{2} \mathrm{O}_{3}$ and $\mathrm{SiC} / \mathrm{B}_{4} \mathrm{C}$ grains. 


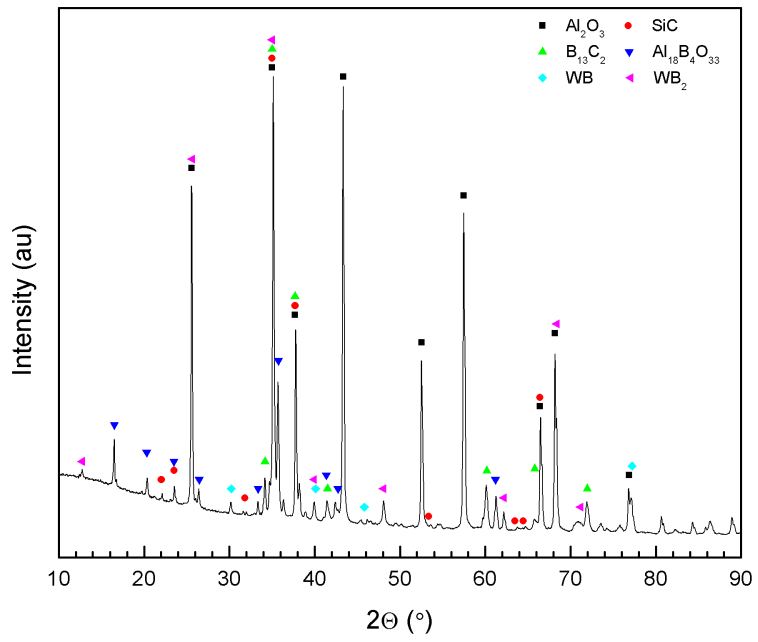



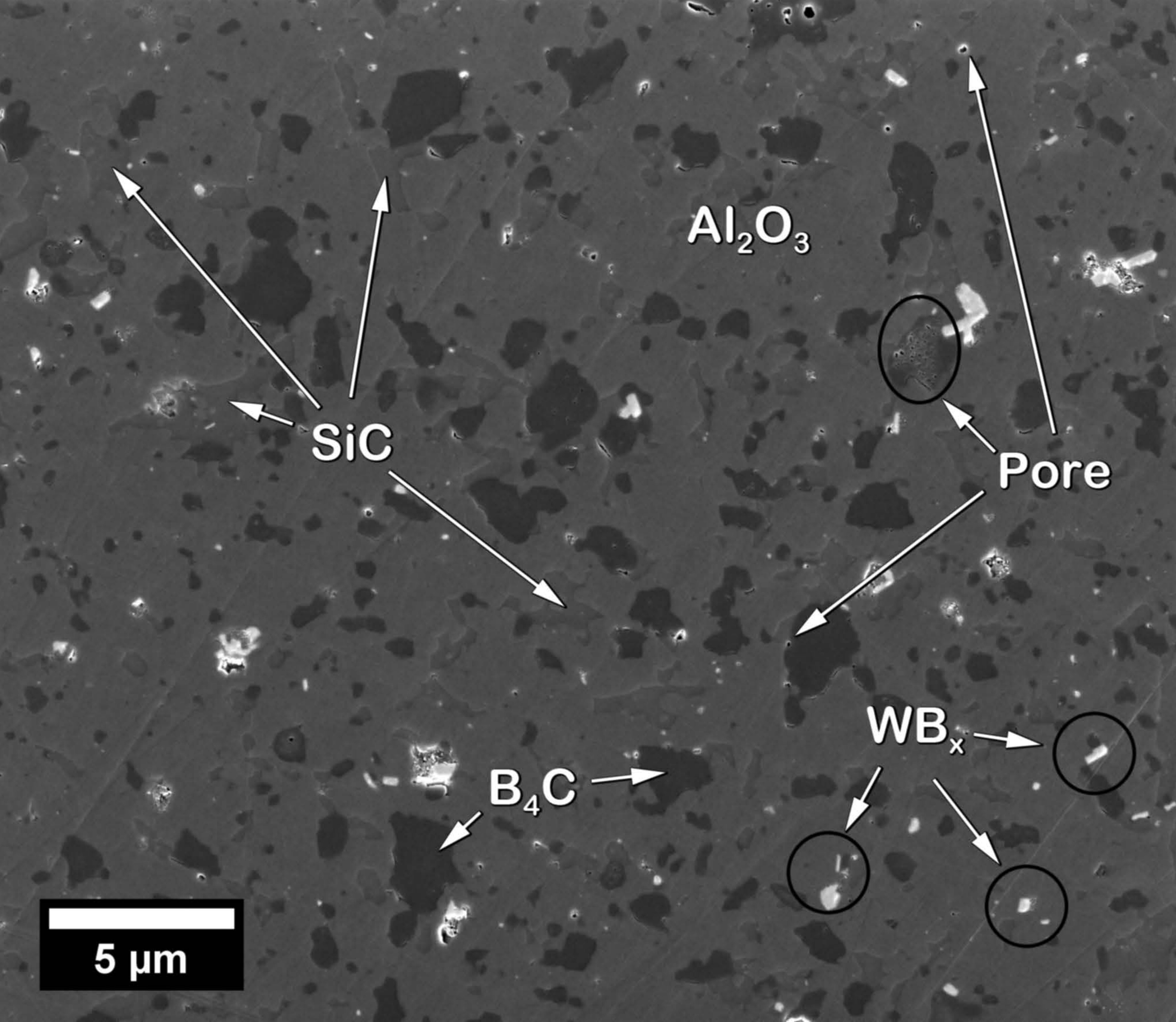


\section{(a)}
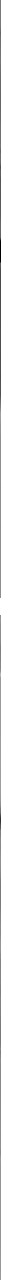


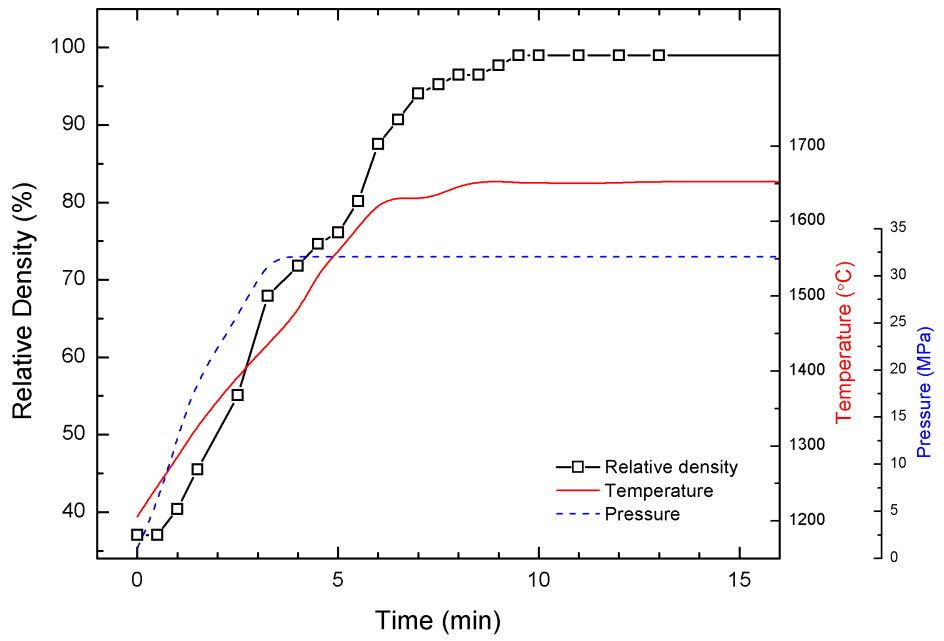


2

$$
\begin{aligned}
& 4^{4}+1>0 \\
& +4 \\
& > \\
& 141
\end{aligned}
$$

$-$

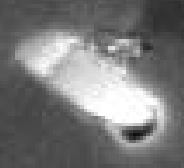

$-$

A.

$$
4
$$

$2 \mu \mathrm{m}$ 